\title{
Introduction to Communication Studies
}

coms 210, Fall 2012

Lecture: MW 11:35-12:25 + 1 weekly conference (beginning 19 September)

McDonald-Harrington G10

You must register for the conference separately; check Minerva for days and times.

As the only required course in our minor, COMS 210 offers an introduction to the field of Communication Studies as it is practiced at McGill. Students will be exposed to some of the major questions facing Communication Studies scholars today, learn how to take positions in important debates, and explore emerging issues in the contemporary media landscape.

Professor Jonathan Sterne

Office \& Mailbox: W280 Arts Building (3rd floor, west wing)

Office Phone: 398-5852 (I check voicemail at least once a day when I'm in and return phone calls once a day)

Mailbox: On My Door

Email: jonathan.sterne@mcgill.ca (list “COMS 210” as the subject of your message)

Office Hours: T 14:30-15:30, W 13:00-14:00 and by appointment

Web presence: http://coms210.net, MyCourses

Teaching Assistant: Morgan Charles

Email: julia.charles@mail.mcgill.ca (note the different name on the email)

Office Hours: TBA

Teaching Assistant: Ryan Diduck

Email: ryan.diduck@mail.mcgill.ca

Office Hours: TBA

Teaching Assistant: Susana Vargas Cervantes

Email: susana.vargascervantes@mail.mcgill.ca

Office hours: TBA

TA office hours and office locations will be announced in class; they begin after add-drop.

Please see the email policy under "course policies" and allow approximately 48 hours for a reply.

Availability: Office hours are set aside for you - feel free to stop by office hours without an appointment. We are happy to see you. The rest of our time is set aside for meetings, class prep, writing, reading, etc. If you wish to see us outside our regular office hours, please make an appointment. Office hours may occasionally be cancelled or rescheduled; this will be announced on the course website or in class.

Other Contacts:

(Name) (Phone) (E-Mail)

(Name)

(Phone)

(E-Mail) 


\section{Requirements and Grading}

You must complete all required major assignments in order to pass this class. You must also register for a conference and attend the same conference each week.

In-Lecture Writing: [10\%] Over the course of the semester, between 3 and 12 pop quizzes and other assignments will occur during lecture. Pop quizzes may cover a reading due on the day of the quiz, any item from the previous two lectures, or other materials you would reasonably be expected to know on a given day. Although they will be closed book and closed note, pop quizzes are designed to be easy, to reward you for keeping up with the course. (If you require special exam accommodations, notify the professor during add-drop). We will drop your two lowest quiz scores (including " 0 " scores for nonattendance). Beyond the two freebies, missed pop quizzes or in-class assignments cannot be made up and are not "excused" for any reason whatsoever.

Final Exam: [28\%] Your centrally scheduled final exam will consist of a group of multiple-choice questions and short-answer questions. University policy requires that I offer supplemental and deferred finals. That final will be worth $28 \%$ of the semester grade and may differ in structure from the regular final exam. There will be a non-credit practice midterm on MyCourses.

Exam Questions: [2\%] Once during the term you will be given the opportunity to submit a question that may be used on the final exam. This assignment cannot be made up.

Conference Participation: [10\%] This mark will represent your performance on short assignments for conference sections and in-class discussion. Your lowest mark will be dropped (for instance, if you miss a session). If you make an exceptional contribution to the course in some other way, it will be recognized in your mark for conference participation. Rude or disruptive behavior toward classmates or teachers will lead to a significant reduction in your semester participation mark, or to a "0" in this category.

Group Presentation: [10\%] Once during the semester, you will be part of a group responsible for a 10-minute presentation on the assigned readings at the beginning of your assigned conference session. Your task will be to come up with a list of questions for the readings and to bring in a real-world example to which the readings could be applied. Dates will be assigned in the first conference session.

Short Papers: [15\%] For most discussion meetings, a few students in each section will each write short 750-1000 word (3-4 page) papers on a pre-assigned topic. Dates will be assigned in the first conference session. Papers are graded according to a standard grid (we will hand it out with the assignment). Because of the volume of papers, we cannot provide other written comments on your finished product. However, we will be happy to meet with you during office hours to talk about your paper.

Term Paper: [25\%] Toward the end of the term, you will submit a single analytical paper on a topic to be announced during the term. Papers are graded according to a standard grid (we will hand this out with the assignment). Because of the volume of papers, we cannot provide other written comments on your finished product. However, we will be happy to meet with you during office hours to talk about your paper. We will also provide you with time off from conferences and extra office hours to meet with us before the paper is due. Additionally, students will have an opportunity to propose alternative projects to the professor should they have a particularly interesting alternative to the analytical paper assignment in mind. 


\section{Resources:}

I. You: "There are those who think that the speaker has a function to perform, and the hearer none. They think it only right that the speaker shall come with his lecture carefully thought out and prepared, while they, without consideration or thought of their obligations, rush in and take their seats exactly as if they had come to dinner, to have a good time while others work hard. Those people bite." - Plutarch, Greek Philosopher

Although this is a large lecture course, your participation is essential. Listen carefully. Take lots of notes on lectures and readings. Take advantage of opportunities to participate. Ask questions in lecture or in conference. Use our office hours.

\section{Your prof and TA: See page 1.}

\section{Required Readings:}

1. Visit McGill's "new" MyCourses (http://www.mcgill.ca/lms/) to check for the official course schedule (and changes thereto), announcements, reading assignments and questions, links to readings, supplemental material, etc. Changes to the class schedule will be announced on the website or in class. You can also use MyCourses for the discussion board, to check your marks, or to take the practice exam (when it's ready). You should visit at least twice a week, or subscribe to stay up to date with announcements, etc.

2. A coursepack, available from the McGill Bookstore and on reserve at McLennan-Redpath Library. Although the course has remained somewhat consistent since Fall 2008, course readings differ slightly each term so if you have a used packet, you will need to go to the library and photocopy new readings. Coursepacks from before 2008 will not be of much use.

3. Additional "recommended readings" may be placed on reserve at the McLennan-Redpath reserve desk, and some material may be available electronically through the course website.

\section{Additional University Resources:}

The University has some additional resources to help you out. These are not remedial programs, and often the best and most advanced students use them:

The Writing Centre offers individual consultation on all aspects of writing. Appointments are required. They can be found at Redpath Main, Room \#02, 398-7109 [http://www.mcgill.ca/mwc/]

The Office for Students with Disabilities (OSD) provides a broad range of support and services to assist students, faculty, and staff with disabilities. They are located in Room RS56, Redpath Library Bldg., 398-6009 (voice), 398-8198 (TTY), [http://www.mcgill.ca/osd/].

Counseling Services provides personal, academic, and career counseling to undergraduate and graduate students. They also offer workshops on study skills, multiple choice exams, test anxiety/stress management. They can be found at suite 4200 Brown Student Services Bldg, 3983601 [http://www.mcgill.ca/counselling/]. An additional list of workshops can be found at [http://www.mcgill.ca/counselling/workshops/]. 


\section{Introduction}

\section{Course Outline and Bibliography}

The Multiplicity of Communication

Peters, John Durham. "Introduction: The Problem of Communication." In Speaking into the Air: A History of the Idea of Communication, 1-31. Chicago: University of Chicago Press, 1999.

\section{Part 1: Theories and Experiences of Communication}

A Transmission Model: Culture and Ideology

Hall, Stuart. "Encoding/Decoding." In Culture, Media, Language: Working Papers in Cultural Studies 1972-9, edited by Stuart Hall, Dorothy Hobson, Andrew Lowe, and Paul Willis, 128-38. London: Hutchinson, 1980.

The Instrumentality Problem

King, Samantha. "A Dream Cause: Breast Cancer, Corporate Philanthropy and the Market for Generosity." In Pink Ribbons, Inc.: Breast Cancer and the Politics of Philanthropy, 1-28 (notes 131-137). Minneapolis: University of Minnesota Press, 2006.

Davison, W. Phillips. "The Third Person Effect in Communication.” Public Opinion Quarterly 47, no. 1 (1983): 1-15.

Ideology Reconsidered

Schudson, Michael. "Advertising as Capitalist Realism." In Advertising, the Uneasy Persuasion, 209-33 (notes 272-75). New York: Basic Books, 1984.

Žižek, Slavoj. "Cynicism as a Form of Ideology." The Sublime Object of Ideology, 24-27. London: Verso, 1989 (note: web versions say it's 28-30 but the book appears to contradict them).

Transmission vs. Ritual

Carey, James. "A Cultural Approach to Communication." In Communication as Culture, 13-36. Boston: Unwin Hyman, 1988.

Sensation and the Saturation Argument

Marvin, Carolyn. "Communication as Embodiment." In Communication As...: Perspectives on Theory, edited by Gregory Shepherd, Jeffrey St. John and Ted Striphas, 67-74. Thousand Oaks: Sage, 2006.

Gitlin, Todd. "Historical Origins of the Torrent," "Distractions, Drugs and Fetishes," and "Calculation and Feeling." In Media Unlimited: How the Torrent of Images and Sounds Overwhelms Our Lives, 24-44 (notes 213-16). New York: Metropolitan Books, 2001.

\section{C: Affiliation and Display}

"Taste Classifies the Classifier"

Affiliation and Display

Goffman, Erving. "Introduction,." In The Presentation of Self in Everyday Life, 1-17. Garden City: Doubleday Anchor Books, 1959.

boyd, danah. "Friends, Friendster and the Top Eight: Writing Community into Being on Social Network Sites." First Monday 11, no. 12 (2006): available online at 
http://www.firstmonday.org/issues/issue11_12/boyd/index.html

Producing Yourself Online

Banet-Weiser, Sarah. "Branding the Post-Feminist Self: Girls' Video Production and

YouTube." In Mediated Girlhoods: New Explorations of Girls' Media Culture, ed. Mary

Celeste Kearney, 277-294. New York: Peter Lang, 2011.

Fashion Theory

Kamamura, Yuniya. "Adoption and Consumption of Fashion." In Fashionology: An Introduction to Fashion Studies, 89-104. New York: Berg, 2005.

Polhemus, Ted. "Trickle Down, Bubble Up. In The Fashion Reader, eds Linda Welters and Abby Lillethun, 327-331. New York: Berg, 2007.

\section{Part 2: Formations of Communication}

\section{A: Understanding Technology}

Making Stuff Happen, or “Wait, I thought we were supposed to read McLuhan in this class?”

Latour, Bruno (as "Jim Johnson"). "Mixing Humans and Nonhumans Together: The Sociology of a Door-Closer." Social Problems 35, no. 1 (1988): 298-310.

Infrastructures

Parks, Lisa "Around the Antenna Tree: The Politics of Infrastructural Visibility" FlowTV 9:9 (2009): http://flowtv.org/2009/03/around-the-antenna-tree-the-politics-ofinfrastructural-visibilitylisa-parks-uc-santa-barbara/

Blum, Andrew, "Netscapes: Tracing the Journey of a Single Bit" Wired Magazine 17:12 (2009): http://www.wired.com/magazine/ff_internetplaces/all/

Starosielski, Nicole, "Beaches, Fields and other Networked Environments," Octopus Journal 5 (2011): http://www.theoctopusjournal.org/storage/volume-5/V5_Starosielski.pdf

Cultural Reverse-Engineering

Balsamo, Anne. "Taking Culture Seriously in the Age of Innovation.” Designing Culture: The Technocultural Imagination at Work, 1-17. Durham: Duke University Press, 2011.

Technological Politics: Case Studies

Faulkner, Tony. "FM: Frequency Modulation or Fallen Man?" in Radiotext(e), edited by Neil Strauss, 61-65. New York: Semiotext(e), 1993.

Goggin, Gerard and Christopher Newell. "Disabling Cell Phones." In The Cell Phone Reader, edited by Anandam Kavoori and Noah Arceneaux, 155-172. New York: Peter Lang, 2006.

\section{B: Follow the Money}

The Media Concentration Argument

Foster, John Bellamy and Robert W. McChesney. “The Internet's Unholy Marriage to Capitalism." Monthly Review 62:10 (2011):

http://monthlyreview.org/2011/03/01/the-internets-unholy-marriage-tocapitalism

You're a Commodity (sort of) 
Lee, Micky. "Google Ads and the Blindspot Debate." Media, Culture and Society 33:3 (2011): 433-447.

You're an Agent (sort of)

Jenkins, Henry. "Buying Into American Idol: How We Are Being Sold on Reality TV." In Convergence Culture: Where Old and New Media Collide, 59-92 (notes 263-266). New York: New York University Press, 2006.

The Economics of Participation

Terranova, Tiziana. "Free Labor: Producing Culture for the Digital Economy." Electronic Book Review (2003): available online at http://www.electronicbookreview.com/thread/technocapitalism/voluntary

\section{C: The Materiality of Ideas}

Redefining "Ownership": the Intellectual Property Problem

Vaidhyanathan, Siva. "Introduction." In Copyrights and Copywrongs: The Rise of Intellectual Property and How It Threatens Creativity, 1-17 (notes 191-194). New York: New York University Press, 2001.

Gillespie, Tarleton. “The Politics of 'Platforms.'” New Media and Society 12:3 (2010): 347364.

The Brand: Commodity, Identity, Touchstone

Klein, Naomi. "New Branded World" and "Alt.Everything: The Youth Market and the Marketing of Cool." In No Logo: Taking Aim at the Brand Bullies, 3-26 and 63-85 (notes 447-48 and 449-51). New York: Picador, 1999.

\section{Schedule of Important Course Dates}

Dates for assigned readings are announced online, and may be subject to change. If I don't mention what's due next in class, feel free to ask me. Otherwise, be sure to check the online course calendar at least once a week. Failure to do so may lead to unfortunate bewilderment in lecture, or worse, showing up to a quiz having read the wrong essay.

Lectures are MW except for as noted below; conferences are W, Th or F. You must attend the conference for which you are registered.

W 5 Sep: First Day of Class. Have rude awakening.

W-F 5-7 Sep: No conference (and no lecture Fri 4 Sep)

W-F 12-14 Sep: No conference (and no lecture Fri $11 \mathrm{Sep}$ )

W 19 Sep: Conferences begin

M 8 Oct: Thanksgiving (no class)

M 19 November: Term paper due.

M 3 Dec: Exam review

Because of the September $4^{\text {th }}$ Quebec election, Wednesday the $5^{\text {th }}$ of December has been made an optional day for MW courses. I will use it for make-up if necessary, otherwise it will be a free day for you to prepare for exams.

Final Exam Date TBA (set by the exam office-believe me, I feel your pain) 


\section{Rules and Expectations (aka "The Business End")}

Failure to follow the letter and the spirit of class or university regulations can result in a reduction of your final grade, failure of the course (or a section thereof), and/or other penalties as set by University policy.

\section{Email Policy}

Email is a useful supplement to other ways of interacting with your teachers, but it is not a substitute for them.

a. If your email requires more than a 3-line answer, come see us during office hours or make an appointment.

b. If your email asks a question that can be answered by looking at the syllabus, website or FAQ, we reserve the right to reply with a one-word reply indicating the location of your answer.

\section{Late Arrivals and Early Departures}

Your professor finds people entering and leaving the classroom during lecture to be distracting. If you know that you must leave early on a given day, please let him know before class. Please make your visits to the bathroom and drinking fountain before and after class. If you arrive late or leave early (or if your excretory system presents you with an emergency in the middle of class) enter or leave the classroom quietly. If you are more than 10 minutes late, don't come to class. Repeat offenders will find their semester grades reduced.

\section{The Classroom: Seating, Questions, and Comments}

Please sit toward the front and center, so that you can hear the lecture and be heard when you ask questions. Although this is a large class, we like discussion. You are encouraged to raise your hand during lecture and ask questions, add comments, or ask for something you didn't understand to be repeated or clarified. When you do, please speak up. The room acoustics can be funny: even if you can hear the prof perfectly, your classmates may not hear you as well.

Mobile phones, smartphones, IM programs, audio players and other gadgets or programs that make noise or distract you or your classmates are not welcome in our classroom. If you must bring them with you, turn them off and put them away. The professor reserves the right to take action against offending devices or their owners. We also reserve the right to require students to shut their laptops if they are facebooking, youtubing, IMing, gaming or doing something else distracting to us or other students.

There will also be at least one laptop-free day during the term, possibly more. If you require a laptop for reasons of disability, you will need to present the professor with a note from Disability Resources and Services to that effect within the first two weeks of class. Students will also have the option of setting a binding laptop policy for the class.

\section{Extensions}

Aside from the quizzes, assignments will be announced well in advance of due dates. If you know well in advance that you can't make a due date for an assignment, please discuss it with us beforehand. If you would prefer a different date for your conference paper or presentation than the one you get, it is your responsibility to switch with someone else and to notify your TA ahead of time.

5. Late Assignments and Missed Exams 
Late papers will be penalized $1 / 3$ of a letter grade per day that they are late, including weekends (e.g., a 2-day late B+ paper counts as a B-). Late assignments will be "excused" only in exceptional and unavoidable circumstances. To get a late assignment excused after the fact, you must submit (a) one typed, double-spaced page explaining the reason for missing the deadline, and (b) relevant documentation such as an official doctor's note on letterhead. The written (not emailed) request for an excuse must be in the professor's hands within one week after the scheduled due date and it is entirely your responsibility to provide sufficient documentation. Note that instructors are not permitted to make special arrangements for final exams. Please consult the Calendar, section 4.7.2.1, General University Information and Regulations for more on the final.

\section{Grades and Appeals}

We take grades very seriously because we know you do. We do not give out grades over email or the telephone. We cannot even disclose that you are enrolled in the course to third parties, including your parents, roommates, boy/girlfriend/spouse, pets, etc.

Should you wish to dispute a mark, it must be done according to the grade appeal policy on the course website. Keep in mind that " $A$ " grades are awarded for superior (and not merely sufficient) performance. Although there is no quota, an " $A$ " is a truly superior grade in this course. Most years, $20-25 \%$ of the enrolled students earned an A or A- semester grade. Also keep in mind that disputes over written work seldom result in an elevated mark and can result in a lower mark (if you ask for your assignment to be regraded, the grade can go up or down).

\section{Language}

The language of instruction at McGill University is English. However, you are allowed to submit your work in French.

\section{Accommodations}

If you require special testing accommodations or other classroom modifications, please notify both the professor and Office for Students with Disabilities by the end of the first week in which you are enrolled in the course. They are located in Room RS56, Redpath Library Bldg., 398-6009 (voice), 398-8198 (TTY), [http://www.mcgill.ca/osd/].

\section{Nondiscrimination Statement}

Your teachers value equality of opportunity, and human dignity and diversity. In accordance with University policy, we will not tolerate discrimination or harassment on the basis of race, color, ethnic or national origin, civil status, religion, creed, political convictions, language, sex, sexual orientation, social condition, age, personal handicap or the use of any means to palliate such a handicap. Among other things, this means that you do not have to agree with your teacher, the assigned readings, or the majority of your classmates in order to do well in this course. You are, however, obligated to demonstrate an understanding of the course material whether or not you agree with it. If there is something we can do to make the class more hospitable, please let us know.

\section{Cheating, Plagiarism and Exam Conduct}

Since we take grades seriously, we also take academic integrity very seriously. Failure to follow procedure or a direct request from your prof or TA during a quiz or exam can result in immediate failure of the exam. Use of any communication devices other than your pen or pencil is forbidden during an in-class quiz. Please note that taking out an electronic communication device (or talking) during a quiz or exam is considered cheating - per Chapter 3, Section A.III.16 of the McGill Handbook of Student Rights and Responsibilities. And now, McGill's official language regarding plagiarism and cheating: 
McGill University values academic integrity. Therefore all students must understand the meaning and consequences of cheating, plagiarism and other academic offences under the code of student conduct and disciplinary procedures (see www.mcgill.ca/integrity for more information).

L'université McGill attache une haute importance à l'honnêteté académique. Il incombe par conséquent à tous les étudiants de comprendre ce que l'on entend par tricherie, plagiat et autres infractions académiques, ainsi que les conséquences que peuvent avoir de telles actions, selon le Code de conduite de l'étudiant et des procédures disciplinaires (pour de plus amples renseignements, veuillez consulter le site www.mcgill.ca/integrity).

\section{Special Required Emergency Syllabus-Eraser Clause}

In the event of extraordinary circumstances beyond the University's control, the content and/or evaluation scheme in this course is subject to change.

\section{What This Class Was Predicted to be Like in $\mathbf{1 9 3 5}$}

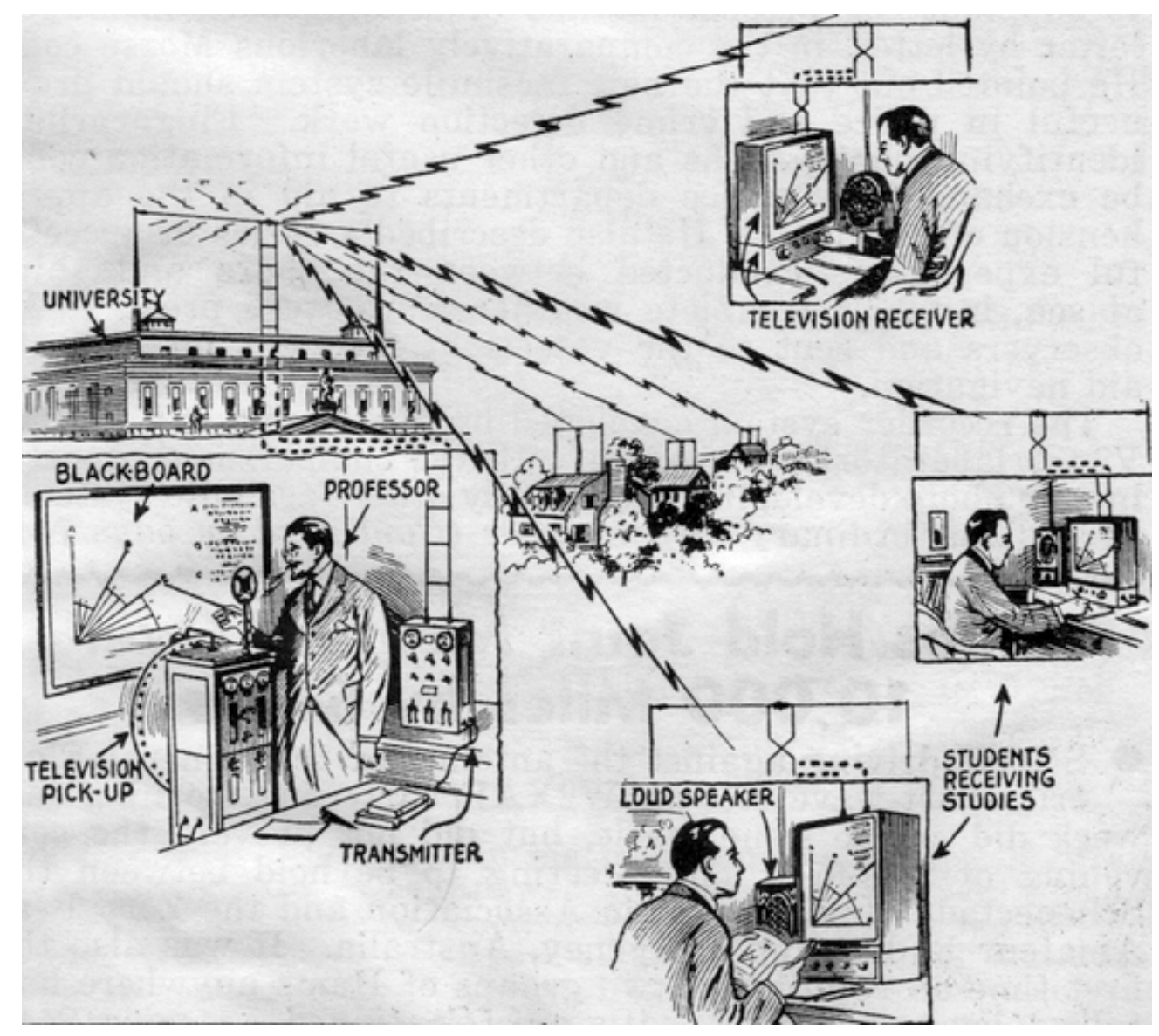

Thanks: Ellie Marshall, Dylan Mulvin, Emily Raine 